\title{
Connections between Teachers' Motivational Behaviour and School Student Engagement
}

\author{
Agne Brandisauskiene ${ }^{1}$, Jurate Cesnaviciene ${ }^{1}$, Ramute \\ Bruzgeleviciene $^{1}$, Rasa Nedzinskaite-Maciuniene ${ }^{1}$
}

${ }^{1}$ Education Academy, Vytautas Magnus University, Kaunas

\section{Lithuania}




\begin{abstract}
Introduction. Teachers are invited to seek answers to many questions on their professional growth path. This article aims at drawing attention to their motivational behaviour in teaching school students. According to the theory of self-determination, appropriate motivating (that is, autonomy-supportive) behaviour of teachers can respond to a child's essential psychological needs, and thus enable him or her to engage in the teaching and learning process. Therefore, the goal of this study is to examine the relationship between teachers' motivational behaviour and student engagement.
\end{abstract}

Method. The sample was composed of 687 students. Two measuring instruments were used: Learning Climate Questionnaire (LCQ) (Black \& Deci, 2000) and Student Engagement Scale (Lam et al., 2014). Descriptive statistics, t test, ANOVA, correlational analyses, and multiple linear regression analyses were used to analyse the data.

Results. The research results suggest that teachers' motivational behaviour (students' perceived level of autonomy-supportive teaching) significantly predicts student engagement. The studied Lithuanian children are characterised by the same engagement as children from all over the world; they see the meaning of their work and focus on it.

Discussion and Conclusion. The conducted research also confirms a universal trend that boys are less involved than girls, although there were no statistically significant differences in the perceived level of teachers' autonomy-supportive behaviour (for boys and girls).

Keywords: autonomy-supportive, engagement, motivational behaviour, self-determination theory. 


\section{Resumen}

Introducción. A los profesores se les anima a buscar respuestas a muchas de las preguntas que surgen durante su crecimiento profesional. En este artículo, nuestra meta es señalar el comportamiento motivador para la enseñanza de sus alumnos. De acuerdo con la teoría de la autodeterminación, los profesores que muestren un comportamiento motivador (es decir, que favorezcan la autonomía) apropiado pueden reaccionar ante las necesidades psicológicas fundamentales de un niño, permitiendo de esta manera su participación en el proceso de enseñanza y aprendizaje. Por tanto, el objetivo de este estudio es examinar la relación entre el comportamiento motivador de los profesores y la participación de los alumnos.

Método. La muestra estuvo compuesta por 687 alumnos. Se emplean dos instrumentos de medida: el Cuestionario de Clima de Aprendizaje (LCQ, por sus siglas en inglés) para alumnos (Black y Deci, 2000) y la Escala de Compromiso Del Alumno (Lam et al., 2014). Se utilizaron estadísticos descriptivos, prueba T para muestras independientes, ANOVA, análisis de correlaciones y análisis de regresión lineal múltiple para analizar los datos.

Resultados. Los resultados de la investigación sugieren que el comportamiento motivador de los profesores (el apoyo percibido por los alumnos a su autonomía por parte de los profesores) predice notablemente la participación de los estudiantes. Los niños lituanos estudiados se caracterizan por mostrar la misma participación que niños del resto del mundo; perciben el significado de su trabajo y se centran en realizarlo.

Discusión y Conclusion: Nuestra investigación también confirma una tendencia universal: que los niños se implican menos que las niñas, aunque no haya diferencias estadísticas significativas en la percepción del comportamiento en favor de la autonomía ejercido por los profesores (para niños y niñas).

Palabras clave: teoría de la autodeterminación, participación, comportamiento motivador, apoyo a la autonomía. 


\section{Introduction}

When training teachers and subsequently planning their professional development guidelines, the range of relevant issues can be extremely wide: from general pedagogical aspects of concern to all educators (e.g. curriculum design, classroom management, use of information computer tools, etc.) to specific subject content subtleties. All of this requires a close look, yet the focus of the present article is on the motivational behaviour of the teacher that influences the learning process of the students.

In the scientific literature, there are various concepts describing teacher behaviour, which has the power to empower or humiliate their students. As researchers note, teachers create the learning climate (Liu, Wang \& Ryan, 2016), use a certain style of teaching (Amoura et al., 2015) or use a certain motivational style (Reeve, 2009; Reeve et al., 2018; Reeve \& Cheon, 2014). Although different concepts are used to describe the influence of teachers on the student learning process, they all reflect teachers' attitudes towards the student and describe behaviour by which the teacher seeks to involve the student into the learning process. This article will explore the concept of teachers' motivational behaviour, which is conceptualised as a motivating way of treating students when the teacher helps students meet their essential psychological needs.

Teaching is closely related to the teacher's personality, and human values (through expectations and attitudes) influence their activities, as "teaching and learning are always social and emotional practices, by design or neglect" (Hargreaves, 2003, p. 60). A caring and attentive relationship can form the basis of a successful pedagogical activity, whereas a negative attitude, a controlling or intimidating relationship, can hinder a student's learning. Obviously, the teacher-student relationship is related both to motivational or non-motivational behaviour of the educator and to the student learning process. According to Reeve (2006), teachers can learn appropriate motivational behaviour, thus helping students to learn and establish growth-promoting relationships. Therefore, this article aims to delve into teachers' motivational (autonomy-supportive) behaviour and its connections with student engagement in the context of self-determination theory (Deci \& Ryan, 2000; Ryan \& Deci, 2000). 


\section{Theoretical background}

According to self-determination theory, children are active and engaged by nature (Deci \& Ryan, 2016). They naturally have a tendency to grow and improve, combining aspects of their experience into a meaningful and increasingly complex whole (Ryan \& Deci, 2017). Consequently, in the learning process, students can be curious, active, strive for excellence and make connections with the social environment. However, as Ryan and Deci (2017) note, this process is not self-contained or automatic. Only meeting the three essential psychological needs - autonomy, competence and relatedness - creates conditions for the internal motivation of the student to learn, function actively, grow and improve. Under the right conditions (in supportive or nurturing environments), young people are able to motivate themselves to learn; they are naturally inclined to take in knowledge and values and to more fully integrate the regulation of behaviours (Deci \& Ryan, 2016; Liu, Wang, \& Ryan, 2016; Niemiec \& Ryan, 2009; Reeve, Jang, \& Jang, 2018). Therefore, the behaviour of the teacher during teaching is especially important, as they can strengthen or inhibit the active functioning of students. It has been determined that in order to encourage children to learn, teachers typically use a motivational style, which can be an autonomy-supportive style or a highly controlling style (Deci et al., 1981; Hornstra et al., 2015; Reeve, Bolt, \& Cai, 1999). If the teacher is characterised by the first (autonomy-supportive) style, he/she stimulates the student's activity, i.e. responds to his/her basic psychological needs, enables the student to actively seek knowledge, learn to solve problems constructively, and feel good. If the teacher is characterised by the latter (highly controlling) style, he/she does not respond to the student's essential needs, which can increase their indifference, encourage them to take no responsibility for their own learning, or make them feel bad.

According to Reeve (2016), there are no two completely identical styles of motivation that support autonomy. Each teacher has their own unique and personal behaviour. Nevertheless, the researcher argues that by looking closely and drawing on the theory of selfdetermination, we can identify certain characteristics of supportive behaviour. "Autonomy support is the instructional effort to provide students with the classroom environment and the teacher-student relationship that can support their students' needs for autonomy. Autonomy support is the interpersonal sentiment and behaviour the teacher provides during instruction, first to identify, then to vitalize and nurture, and eventually to develop, strengthen, and grow students' inner motivational resources" (Reeve, 2016, p. 130). Obviously, teachers with an 
autonomy-supportive style rely on different instructional behaviours to motivate their students than do teachers with a controlling style (Reeve \& Jang, 2006).

Depending on the teacher's motivational style and his or her instructional behaviour, students' active and conscious learning and learning outcomes can vary widely. Research results demonstrate that teachers' autonomy-supportive behaviour is associated with higher student motivation, effective student engagement in learning, and positive learning outcomes (Cheon et al., 2018; Gunnell et al., 2013; Jang, Kim, \& Reeve, 2016). Meanwhile, a controlling teaching style is associated with lower student motivation, ineffective, superficial learning, and low learning achievement (Haerens et al., 2015; Hein, Koka, \& Hagger, 2015). Although teacher motivational behaviour can be linked to various aspects of student learning, the present article delves deeper into its links with student engagement; hence, the aforesaid phenomenon will be briefly discussed.

Engagement is a construct encompassing some dimensions of involvement in school or commitment to learning (Lam et al., 2014; Reeve, 2012). We can see and assess the student's (1) cognitive engagement - his or her usage of sophisticated rather than superficial learning strategies; (2) emotional engagement - the presence of task-facilitating emotions such as interest; (3) behavioural engagement - his or her concentration, attention, and effort; and (4) agentic engagement - the extent to which she tries to enrich the learning experience rather than just passively receive it as a given (Reeve, 2012, p. 150). It is clear that engagement has a positive connotation, i.e. a positive learning-related state characterised by vigour, dedication and observation. However, the phenomenon of student engagement is complex and can vary according to age (Fernández-Zabala et al., 2016; Havik \& Westergård, 2020), gender (Fernández-Zabala et al., 2016; Havik \& Westergård, 2020; Lam et al., 2012, 2016), or be momentary (Strati, Schmidt, \& Maier, 2015). Student engagement can be seen as a significant predictor of teacher emotions (Hagenauer, Hascher, \& Volet, 2015), but it is important to note that higher levels of student engagement are associated with higher academic achievement and future success (Harbour et al., 2015). As has already been mentioned, research shows that teachers' motivating behaviour is related to students' involvement in the teaching/learning process (Appleton, Christenson, \& Furlong, 2008; Jang, Kim, \& Reeve, 2016; Reeve, 2006, 2009; Reeve \& Cheon, 2014). Moreover, the teacher's autonomy-supportive techniques, competence scaffolds, and feedback approaches influence students' motivation and performance outcomes (Ryan \& Deci, 2019). According to Evans 
and Boucher (2015, p. 87), this "choice plays a critical role in promoting students' intrinsic motivation and deep engagement in learning"; therefore, it is important to investigate whether such conditions are created for students.

\section{Objectives}

The goal of this study is to examine the relationship between teachers' motivational (autonomy-supportive) behaviour and students' engagement. The research questions are as follows:

1) How do students perceive the autonomy support of their teacher?

2) How do boys and girls differ in engagement?

3) What relationships exist between perceived autonomy support from teachers and student engagement?

\section{Method}

\section{Participants}

The study was conducted on a convenience sample of seventh- through ninth-grade students (313 boys and 374 girls) from different general education schools (lower secondary school and higher secondary school) in Lithuania. The participants were enrolled in seventh (43.8\%), eighth (35.7\%), and ninth (20.5\%) grades. Sample distribution according to gender, grade and school type is shown in Table 1.

Table 1. Research sample by gender, grade, and school type

\begin{tabular}{llcccccc}
\hline & & \multicolumn{2}{c}{ Boys } & \multicolumn{2}{c}{ Girls } & \multicolumn{2}{c}{ Total } \\
\cline { 3 - 7 } & & $N$ & $\%$ & $N$ & $\%$ & $N$ & $\%$ \\
\hline \multirow{4}{*}{ Grade } & $7^{\text {th }}$ grade & 141 & 45.0 & 160 & 42.7 & 301 & 43.8 \\
& $8^{\text {th }}$ grade & 112 & 35.8 & 133 & 35.6 & 245 & 35.7 \\
& $9^{\text {th }}$ grade & 60 & 19.2 & 81 & 21.7 & 141 & 20.5 \\
& Total & 313 & 100 & 374 & 100 & 687 & 100 \\
\hline \multirow{3}{*}{ Schools } & Lower secondary school & 133 & 42.5 & 160 & 42.8 & 293 & 42.6 \\
& Higher secondary school & 180 & 57.5 & 214 & 57.2 & 394 & 57.4 \\
& Total & 313 & 100 & 374 & 374 & 687 & 100 \\
\hline
\end{tabular}

\section{Instruments}

The first section of the students' questionnaire concerned the socio-demographic data (gender, grade), school type (lower or higher secondary school). The second section consisted 
of the short form of the Learning Climate Questionnaire (LCQ) (Black \& Deci, 2000) and measured how students perceive autonomy support provided by their teachers. This questionnaire consisted of 6 items answered on a 7-point Likert scale from 1 (strongly disagree) to 7 (strongly agree) with an intermediate score of 4 (moderately agree). The sample item was: "I feel that my teacher provides me choices and options". The scores on the 6-item LCQ were calculated by averaging the individual item scores. Higher scores indicated greater perceived autonomy support. The third section was intended for the student engagement. It was measured by Student Engagement Scale (Lam et al., 2014). This scale consists of three subscales, namely Affective Engagement, Behavioural Engagement, and Cognitive Engagement. Each item of two subscales - Affective Engagement and Behavioural Engagement - was rated on a 5-point Likert scale, ranging from 1 (strongly disagree) to 5 (strongly agree). The example of Affective Engagement subscale item was: "I am happy to be at this school". The sample item of Behavioural Engagement subscale was: "I pay attention in class". The Cognitive Engagement item (e.g., "When learning new information, I try to put the ideas in my own words") was scored on a 5-point Likert scale from 1 (almost never) to 5 (almost always). The average for each subscale was derived. High scores indicated high levels of engagement.

The Learning Climate Questionnaire was downloaded from the website https://selfdeterminationtheory.org. A written permission to use this measure was obtained by the first author of this article. The written permission to use Student Engagement Scale was obtained from Shui-fong Lam. The translation of questionnaires was organized following the procedure of back-forward translation according to the recommendations prepared by Van de Vijver and Hambleton (1996). Both questionnaires were translated from English into Lithuanian by the first author of this article. The translated questionnaires were reviewed by the Lithuanian language expert. This was followed by a bilingual (Lithuanian and English speaking) translator translating the instrument back into the English language. The backtranslated and original questionnaires were reviewed and analyzed by the authors of this publication. The final version of the translated questionnaire was pilot tested on a small sample of student.

In this study, the internal cohesion of the Learning Climate Questionnaire and the Student Engagement Scale was checked with Cronbach's $\alpha$ test. The Cronbach's alpha of .70 or higher for a set of items is considered aceptable (Cohen, Manion, \& Morrison, 2018). The 
Cronbach's alpha coefficient, which measures the internal consistency of the LCQ items, was satisfactory $(\alpha=.887)$. The Cronbach's alpha coefficient attained high values for all three subscales of the Student Engagement Scale (Table 2). The finding of Cronbach's alpha $(\alpha=.926)$ suggests that the whole Student Engagement Scale also has an acceptable internal consistency.

Table 2. Cronbach's alpha of subscales of the Student engagement scale

\begin{tabular}{lccc}
\hline \multicolumn{1}{c}{ Subscales } & Number of items & $\begin{array}{c}\text { Cronbach } \alpha \\
\text { in this study }\end{array}$ & $\begin{array}{c}\text { Cronbach } \alpha \\
\text { (Lam et al., 2014) }\end{array}$ \\
\hline Affective Engagement & 9 & 0.873 & 0.84 \\
Behavioural Engagement & 12 & 0.795 & 0.80 \\
Cognitive Engagement & 12 & 0.925 & 0.89 \\
\hline
\end{tabular}

\section{Procedure}

The research data were collected in January and February 2020. After receiving the school principal's approval to carry out the research, the students and their parents were informed of the aim and procedure of the study. Since the students were minors, their parents were informed about the study, the voluntary nature of the study, confidentiality and anonymity, and were given the option to have their child(ren) not participate in the study. The students and their parents agreed to participate in the study themselves. The questionnaires were completed on computers during a lesson.

The research was conducted following the nationally approved ethic code of the Lithuanian Scholar. The respondents were invited to participate in the study on the voluntary basis and all personal information related to gender, age and organisation was anonymised. These principles were always clearly stated in the research instruments and consent forms. The research was consistently conducted following the described methodology and based on the relevant theories. The researchers declare that the results of the empirical research do not evoke any conflicts of interests.

\section{Datal Analysis}

The statistical analyses were performed using IBM SPSS Statistics 22.0. For descriptive research, the data were processed and analysed using frequency, percentage, mean, and standard deviation. Associations between Learning Climate Questionnaire and 
Student Engagement Scale were assessed by Pearson correlation (r). A correlation of $<.19$ is considered very weak, .20-.39 weak, .40-.59 moderate, .60-.79 strong, > .80 very strong (for positive as well as negative values) (Cohen, 1988). For a sample size $>300$, normality of the data depends on the absolute values of skewness and kurtosis. Either an absolute skewness value $\leq 2$ or an absolute kurtosis (excess) $\leq 4$ may be used as reference values for determining considerable normality (West, Finch, \& Curran, 1995). Therefore, parametric statistics was used for all analyses. According to gender differences, the students' perceived autonomy support from their teacher and engagement were assessed by Student's t-tests. The difference between the 7th-grade, 8th-grade, and 9th-grade students was determined by ANOVA. Cohen's d was calculated and the effect size was examined. For Cohen's d, a value of .20 is interpreted as a small effect, .50 is a medium effect, and .80 is a large effect (Cohen, Manion, \& Morrison, 2018).

Multiple linear regression analyses were used to examine the association of gender, 7th-9th grade, and teacher's autonomy support with student engagement. In regression analysis, the effect size of the predictor variables is given by the beta loadings. In interpreting the effect, size gives the following guidance: 0-.1 weak effect, .1-.3 modest effect, .3-.5 moderate effect, and > .5 strong effect (Cohen, Manion, \& Morrison, 2018). A statistical significance was set at $\mathrm{p}<.05$ for all tests.

\section{Results}

Table 3 presents the descriptive statistics, which include mean, standard deviation, values of skewness and kurtosis, and mode. The results revealed that the variables are approximately normally distributed based on the degree of skewness and kurtosis as both were less than 1. Students generally reported moderate levels of perceived teachers' autonomy-supportive behaviour. Students were moderately engaged across all the three dimensions: affective, behavioural, and cognitive.

\section{Table 3. Descriptive statistics for each variable across the whole sample}

\begin{tabular}{cccccc}
\hline Scales and Subscales & Mean & SD & Mode & Skewness & Kurtosis \\
\hline Learning Climate Questionnaire & 4.03 & 1.34 & 4.00 & -0.171 & -0.362 \\
Student Engagement Scale: & 3.23 & 0.56 & 3.00 & -0.403 & 0.879 \\
Affective Engagement Subscale & 3.11 & 0.72 & 3.11 & -0.336 & -0.150 \\
Behavioural Engagement Subscale & 3.34 & 0.57 & 3.42 & -0.300 & 0.759 \\
Cognitive Engagement Subscale & 3.20 & 0.77 & 3.00 & -0.359 & 0.434 \\
\hline
\end{tabular}


The results of the independent samples T-tests are summarised in Table 4. According to the results, girls and boys were not significantly different in terms of perceived teachers' autonomy-supportive behaviour $(p=.317)$. In relation to engagement, there were significant differences between boys and girls in the behavioural $(p<.0001)$ and cognitive $(p=.009)$ dimensions, while the differences were not significant for affective engagement $(p=.055)$. Finally, the effect size was small ( $d=.34$ for behavioural engagement; $d=.20$ for cognitive engagement).

Table 4. Independent samples of t-test results for differences of variables in terms of gender

\begin{tabular}{|c|c|c|c|c|c|c|}
\hline \multirow{2}{*}{ Scales and Subscales } & \multirow{2}{*}{ Gender } & \multirow{2}{*}{ Mean } & \multirow{2}{*}{$S D$} & \multicolumn{2}{|c|}{ t-tests } & \multirow{2}{*}{ Cohen's d } \\
\hline & & & & $t$ & $p$ & \\
\hline \multirow{2}{*}{ Learning Climate Questionnaire } & Girls & 3.99 & 1.32 & \multirow{2}{*}{1.001} & \multirow{2}{*}{0.317} & \multirow{2}{*}{0.07} \\
\hline & Boys & 4.09 & 1.37 & & & \\
\hline \multirow[t]{2}{*}{ Student Engagement Questionnaire } & Girls & 3.30 & 0.53 & \multirow{2}{*}{-3.591} & \multirow{2}{*}{0.0001} & \multirow[b]{2}{*}{0.29} \\
\hline & Boys & 3.14 & 0.58 & & & \\
\hline \multirow{2}{*}{ Affective Engagement Subscale } & Girls & 3.16 & 0.67 & \multirow{2}{*}{-1.923} & \multirow{2}{*}{0.055} & \multirow{2}{*}{0.15} \\
\hline & Boys & 3.05 & 0.77 & & & \\
\hline \multirow{2}{*}{ Behavioural Engagement Subscale } & Girls & 3.42 & 0.53 & \multirow{2}{*}{-4.343} & \multirow{2}{*}{0.0001} & \multirow{2}{*}{0.34} \\
\hline & Boys & 3.23 & 0.60 & & & \\
\hline \multirow{2}{*}{ Cognitive Engagement Subscale } & Girls & 3.27 & 0.74 & \multirow{2}{*}{-2.624} & \multirow{2}{*}{0.009} & \multirow{2}{*}{0.20} \\
\hline & Boys & 3.12 & 0.79 & & & \\
\hline
\end{tabular}

In order to test for the existence of differences by grade, Table 5 shows the results of ANOVA test corresponding to students' perception of teachers' autonomy-supportive behaviour and engagement, respectively. The test indicated that neither was significantly different.

Table 5. ANOVA test results for differences of variables in terms of 7th-10th grade

\begin{tabular}{lcccccc}
\hline \multicolumn{1}{c}{ Scales and Subscales } & Grade & Mean & SD & $\begin{array}{c}\text { Mean } \\
\text { Square }\end{array}$ & $\begin{array}{c}\text { ANOVA test } \\
\text { F }\end{array}$ \\
\hline \multirow{3}{*}{ Learning Climate Questionnaire } & $7^{\text {th }}$ grade & 3.94 & 1.38 & & & \\
& $8^{\text {th }}$ grade & 3.99 & 1.33 & 6.830 & 3.808 & 0.023 \\
& $9^{\text {th }}$ grade & 4.31 & 1,26 & & & \\
Student Engagement Questionnaire & $7^{\text {th }}$ grade & 3.20 & 0.59 & & & \\
& $8^{\text {th }}$ grade & 3.22 & 0.54 & 0.247 & 0.786 & 0.456 \\
& $9^{\text {th }}$ grade & 3.28 & 0.54 & & & \\
Affective Engagement Subscale & $7^{\text {th }}$ grade & 3.09 & 0.72 & & & \\
& $8^{\text {th }}$ grade & 3.06 & 0.73 & 1.529 & 2.970 & 0.052 \\
& $9^{\text {th }}$ grade & 3.24 & 0.69 & & & \\
Behavioural Engagement Subscale & $7^{\text {th }}$ grade & 3.34 & 0.57 & & & \\
& $8^{\text {th }}$ grade & 3.34 & 0.56 & 0.037 & 0.114 & 0.892 \\
& $9^{\text {th }}$ grade & 3.32 & 0.58 & & & \\
Cognitive Engagement Subscale & $7^{\text {th }}$ grade & 3.15 & 0.81 & & & \\
& $8^{\text {th }}$ grade & 3.23 & 0.74 & 0.750 & 1.273 & 0.281 \\
& $9^{\text {th }}$ grade & 3.26 & 0.72 & & & \\
\hline
\end{tabular}


Table 6 presents the relationships among students' perceived autonomy supportive behaviour from teachers, measured by Learning Climate Questionnaire, with student engagement. Positive statistically significant moderate correlations were found between perceived autonomy support from teachers and students' affective engagement $(r=.534, p<$ $.01)$, and cognitive engagement $(r=.513, \mathrm{p}<.01)$. The positive statistically significant weakest correlation was determined in perceived autonomy support from teachers and students' behavioural engagement $(r=.373, p<.01)$.

Table 6. Bivariate correlations between the variables

\begin{tabular}{ccccc}
\hline Scales and Subscales & 1 & 2 & 3 & 4 \\
\hline (1) Learning Climate Questionnaire (LCQ) & 1 & & & \\
(2) Student Engagement Scale: & $0.580^{* *}$ & 1 & & \\
(3) Affective Engagement Subscale & $0.534^{* *}$ & $0.792^{* *}$ & 1 & \\
(4) Behavioural Engagement Subscale & $0.373^{* *}$ & $0.817^{* *}$ & $0.568^{* *}$ & 1 \\
(5) Cognitive Engagement Subscale & $0.513^{* *}$ & $0.844^{* *}$ & $0.464^{* *}$ & $0.497^{* *}$ \\
\hline
\end{tabular}

Note: $* *$ Correlation is significant at the 0.01 level (2-tailed)

The multiple linear regression analysis was implemented to determine the influence of perceived autonomy support from teachers on the engagement dimensions (Table 7). A positive and significant model was found for students' affective engagement $\left(R^{2}=.294 ; F=\right.$ 94.769, $p<.0001)$ and students' cognitive engagement $\left(R^{2}=.277 ; F=37.336, p<.0001\right)$. The regression analysis results also suggest a positive and significant model for students' behavioural engagement $\left(R^{2}=.174 ; F=47.930, p<.0001\right)$. In turn, the adjusted coefficients of determination show that the affective engagement model (adjusted $R^{2}=.291$ ) and cognitive engagement model have high explanatory power (adjusted $R^{2}=.274$ ), and that the behavioural engagement models have moderate predictive power (adjusted $R^{2}=.17$ ).

The standardised beta coefficient values confirm that the variable with the greatest loadings in the three models is teacher support. The results indicated that students' perceived autonomy supportive behaviour from teachers significantly predicted affective engagement $(\beta$ $=.536, p<.0001)$ and cognitive engagement $(\beta=.516, p<.0001)$. These beta loadings disclosed a strong effect. The results also revealed that students' perceived autonomy 
supportive behaviour from teachers $(\beta=.385, p<.0001)$ had a significant moderate effect on behavioural engagement.

Gender as a predictor had a significant modest effect on behavioural engagement $(\beta=$ $.18, p<.0001)$ and cognitive engagement $(\beta=.119, p<.0001)$. Meanwhile, the grade was not a predictor of any engagement dimension.

Table 7. Predictions of student engagement

\begin{tabular}{|c|c|c|c|c|c|}
\hline Predictors & $\begin{array}{c}\text { Unstandardised } \\
\text { Coefficients B }\end{array}$ & Std. Error & $\begin{array}{c}\text { Standardised } \\
\text { Coefficients } \\
\beta\end{array}$ & $t$ & $p$ \\
\hline \multicolumn{6}{|c|}{ Affective Engagement $\left(\mathrm{R}^{2}=0.294 ; \mathrm{F}=94.769, \mathrm{p}<0.0001\right)$} \\
\hline Constant & 1.724 & 0.113 & & 15.209 & 0.0001 \\
\hline $\begin{array}{l}\text { Perceived auton } \\
\text { support from } \\
\text { teachers }\end{array}$ & 0.287 & 0.017 & 0.536 & 16.589 & 0.0001 \\
\hline Gender & 0.136 & 0.046 & 0.094 & 2.928 & 0.004 \\
\hline Grade & 0.011 & 0.030 & 0.011 & 0.347 & 0.729 \\
\hline \multicolumn{6}{|c|}{ Behavioural Engagement $\left(\mathrm{R}^{2}=0.174 ; \mathrm{F}=47.930, \mathrm{p}<0.0001\right)$} \\
\hline Constant & 2.436 & 0.097 & & 25.049 & 0.0001 \\
\hline $\begin{array}{l}\text { Perceived auton } \\
\text { support from } \\
\text { teachers }\end{array}$ & 0.163 & 0.015 & 0.385 & 11.011 & 0.0001 \\
\hline Gender & 0.206 & 0.040 & 0.180 & 5.175 & 0.0001 \\
\hline Grade & -0.044 & 0.026 & -0.059 & -1.678 & 0.094 \\
\hline \multicolumn{6}{|c|}{ Cognitive Engagement $\left(\mathrm{R}^{2}=0.277 ; \mathrm{F}=37.336, \mathrm{p}<0.0001\right)$} \\
\hline Constant & 1.718 & 0.122 & & 14.035 & 0.0001 \\
\hline $\begin{array}{l}\text { Perceived auton } \\
\text { support from } \\
\text { teachers }\end{array}$ & 0.295 & 0.019 & 0.516 & 15.789 & 0.0001 \\
\hline Gender & 0.184 & 0.050 & 0.119 & 3.661 & 0.0001 \\
\hline Grade & 0.007 & 0.033 & 0.007 & 0.209 & 0.835 \\
\hline
\end{tabular}




\section{Discussion and conclusion}

In this research, two constructs (the students' perceived autonomy support of their teachers and their engagement) and the relationships between them were investigated. The students generally reported moderate levels of perceived teachers' autonomy-supportive behaviour, and students were moderately engaged across all the three dimensions of engagement. Lam et al. (2016) performed a study in 14 countries (Austria, Canada, China, Cyprus, Estonia, Greece, Malta, Portugal, Romania, South Korea, the United Kingdom, and the United States) and determined that students of this age had a similar level of involvement. However, another universal trend should be pointed out: the present research confirmed the phenomenon of a gender gap in student engagement. This regularity is supported by the results of various studies (Fernández-Zabala et al., 2016; Havik \& Westergård, 2020; Lam et al., 2012) and this trend does not vary across the countries according to cultural values and socioeconomic development (Lam et al., 2016). Hence, the results of the student engagement research confirmed the insights of researchers of 14 countries that girls tend to be more engaged than boys (Lam et al., 2012, 2016). On the other hand, the present research determined that girls and boys were not significantly different according to perceived teachers' autonomy supportive behaviour. This differs from the results of other researchers who suggest that there is a gender gap in perceptions of teacher support (Lietaert et al., 2015).

Moreover, no differences according to the age of the students were found in the present study. As mentioned earlier, various scholarly works differentiate between younger and older students: in higher grades, students tend to be less involved (Havik \& Westergård, 2020; Lam et al., 2012, 2016), and this universal trend that older students report lower engagement levels in school is disconcerting (Lam et al., 2016). On the one hand, the result of the research could be explained by the fact that children of similar age ( 7 th -9 th grades) were studied, whereas, for example, Havik and Westergård (2020) found differences in emotional engagement when comparing primary school and lower secondary school students. The latter were less engaged emotionally than the former. However, researchers from 14 countries studied the same engagement methodology and the same grades (7th - 9th grades) and found that the results revealed a decline in engagement from Grade 7 to Grade 9 (Lam et al., 2012, 2016). Thus, the results of this studies are similar in terms of gender but differ in terms of age. 
The present research aimed at finding out what relationships exist between perceived autonomy support from teachers and student engagement and can foresee student engagement. Statistically significant positive correlations were determined between perceived autonomy support from teachers and student engagement (affective, cognitive and behavioural). Students' perceived autonomy support from teachers strongly predicted affective engagement and cognitive engagement and had a significant moderate effect on behavioural engagement. This confirms the statement that "student engagement needs supportive conditions, especially supportive student-teacher relationships" (Reeve, 2012, p. 152). It is assumed that motivating teacher behaviour is fundamentally related to a respectful relationship. Thus, this relationship can be defined as a "dialogue" that significantly encourages the student not to be afraid to express their thoughts or to make mistakes, to ask problematic questions, and to seek answers. Therefore, it should be pointed out that behaviour promoting student autonomy does not mean devaluation of the teacher's work or unnecessary teaching. Providing autonomy support does not mean that teachers are "permissive" and allow students to do whatever they want, rather teachers provide structure (aims, clear guidelines) (Deci \& Ryan, 2016). Instruction remains an essential element in the educational process, yet it provides opportunities for the student to make choices. It is these conditions that encourage the student to be more interested in the subject or involved in learning. If teachers take into account which topics or aspects of a topic students would like to learn about more broadly, in what ways they want to learn, the students are given choices that presuppose respect for their opinions and respond to their essential needs. According to Reeve and Jang (2006, p. 216), “when autonomously motivated, students' intentional behaviours emerge out of an internal locus of causality, high volition, and a sense of choice over their actions". Hence, the theory of self-determination increasingly reveals that good quality relationships are a source of motivation for students to learn.

\section{Limitations}

The present work has some limitations. An engagement instrument that measures the three dimensions of this construct was chosen for the study. Scientists are now discussing and measuring the fourth (agentic engagement) dimension. It is obvious that it is meaningful and important to measure students' agentic engagement, but in this case, the instrument of Lam et al. (2014) was used to compare the results of the present study with those of 14 other countries. Student self-report forms were also used to determine their motivational behaviour. On the one hand, this could be a limitation of the study as other research methods (e.g. 
observation) could complement the available data; on the other hand, though, it can be maintained that students' self-reports were sufficient to collect the data because looking at students as capable of autonomous learning, one must also have confidence in their ability to assess their and their teachers' behaviour reliably and objectively.

\section{Practical implementations and further research}

This study is not only important in diagnostic terms, but also has practical value. Teachers can realistically test their motivational style by asking students to complete the Students' Learning Climate Questionnaire (a short version of which was used in this study). It is important to understand that autonomy-supportive motivating behaviour is malleable, and can be learnt (Reeve, 2006). Thus, a teacher's reflection on his or her motivational behaviour (and all other issues) is one of the essential starting points for improving his or her students' learning. The role of school principals or leaders is also very important. Realising that "teacher behaviour is a critical factor in increasing student engagement and academic achievement" (Harbour et al., 2015, p. 10), teachers using an autonomy-supportive style must work themselves in a supportive environment (Reeve, 2009). So the new direction for future research would involve how the work environment supports educators and helps them to exchange their inner motivational resources, rather than shape, change or control them.

In conclusion, the research data confirmed universal phenomena: student engagement varies by gender, whereas perceived autonomy support from teachers significantly predicts engagement. The studied Lithuanian children are the same as students from all over the world: they are equally involved in education, see the meaning of their work and focus on learning. Thus, although different cultural and social conditions for teaching and learning exist in different countries, the same patterns in the phenomena of student engagement and teacher motivational behaviour are observed. The process of meeting essential psychological needs may explain how the interaction between an inherently active student and an appropriate (autonomy-supportive) learning environment results in greater student involvement in the learning process. Autonomy-supportive behaviour is the behaviour of a teacher which gives the student the opportunity to choose how to behave. In this case, the teacher is sensitive to the student's needs, trusts him or her, and promotes his or her independence. It is essential that the teacher shows respect for students' individuality and communicates openly and flexibly (Haerens et al., 2018). On the other hand, it should be recognised that there are no unambiguous answers when educating students. Various 
pedagogical, psychological, social and cultural factors intertwine here, so every piece of research is very important, as they confirm certain phenomena or encourage looking for the reasons and factors in various educational environments why results of research differ.

\section{References}

Amoura, C., Berjot, S., Gillet, N., Caruana, S., Cohen, J., \& Finez, L. (2015). Autonomy-supportive and controlling styles of teaching: Opposite or distinct teaching styles? Swiss Journal of Psychology, 74(3), 141-158. doi:10.1024/1421-0185/a000156

Appleton, J. J., Christenson, S. L., \& Furlong, M. J. (2008). Student engagement with school: Critical conceptual and methodological issues of the construct. Psychology in the Schools, 45(5), 369386. doi:10.1002/pits.20303

Black, A. E., \& Deci, E. L. (2000). The effects of instructors' autonomy support and students' autonomous motivation on learning organic chemistry: A self-determination theory perspective. Science Education, 84, 740-756. doi:10.1002/1098237X(200011)84:6<740::AID-SCE4>3.0.CO;2-3

Cheon, S. H., Reeve, J., Lee, J., \& Lee, Y. (2018). Why autonomy-supportive interventions work: Explaining the professional development of teachers' motivating style. Teaching and Teacher Education, 69, 43-51. doi:10.1016/j.tate.2017.09.022

Cohen, J. (1988). Statistical power analysis for the behavioral sciences (2nd ed.). Hillsdale, NJ: Lawrence Erlbaum Associates.

Cohen, L., Manion, L., \& Morrison, K. (2018). Research Methods in Education (8nd ed.). New York: Routledge.

Deci, E. L., Schwartz, A., Sheinman, L., \& Ryan, R. M. (1981). An instrument to assess adult's orientations toward control versus autonomy in children: Reflections on intrinsic motivation and perceived competence. Journal of Educational Psychology, 73, 642-650.

Deci, L. E., \& Ryan, R. M. (2000). The ,what'and ,why' of goal pursuits: Human needs and the selfdetermination of behavior. Psychological Inquiry, 11, 227-268. doi:10.1207/S15327965PLI1104_01

Deci, L. E., \& Ryan, R. M. (2016). Optimizing students' motivation in the era of testing and pressure: A self-determination theory perspective. In: W. C. Liu, L. C. K. Wang and R. M. Ryan (red.). Building autonomous learners: Perspectives from research and practice using selfdetermination theory (pp. 9-29). Singapore: Springer.

Evans, M., \& Boucher, A. R. (2015). Optimizing the power of choice: supporting student autonomy to foster motivation and engagement in learning. Mind, Brain, and Education, 9(2), 87-91. doi:10.1111/mbe.12073 
Fernández-Zabala, A., Goni, E., Camino, I., \& Zulaika, L. M. (2016). Family and school context in school engagement. European Journal of Education and Psychology, 9, 47-55. doi:10.1016/j.ejeps.2015.09.001

Gunnell, K., Crocker, P. R. E., Wilson, P. M., Mack, D. E., \& Zumbo, B. D. (2013). Psychological need satisfaction and thwarting: A test of basic psychological needs theory in physical activity contexts. Psychology of Sport and Exercise, 14(5), 599-607. doi:10.1016/j.psychsport.2013.03.007

Haerens, L., Aelterman, N., Vansteenkiste, M., Soenens, B., \& Van Petegem, S. (2015). Do perceived autonomy-supportive and controlling teaching relate to physical education students' motivational experiences through unique pathways? Distinguishing between the bright and dark side of motivation. Psychology of Sport and Exercise, 16(3), 26-36. doi:10.1016/j.psychsport.2014.08.013

Haerens, L., Vansteenkiste, A., De Meester, A., Delrue, J., Tallir, I., Vande Broek, G., Goris, W., \& Aelterman, N. (2018). Different combinations of perceived autonomy support and control: identifying the most optimal motivating style. Physical Education and Sport Pedagogy, 23(1), 16-36. doi:10.1080/17408989.2017.1346070

Hagenauer, G., Hascher, T., \& Volet, S. E. (2015). Teacher emotions in the classroom: associations with students' engagement, classroom discipline and the interpersonal teacher-student relationship. European Journal of Psychology of Education, 30, 385-403. doi:10.1007/s10212015-0250-0

Harbour, K. E., Evanovich, L. L., Sweigart, C. A., \& Hughes, L. E. (2015). A brief review of effective teaching practices that maximize student engagement. Preventing School Failure: Alternative Education for Children and Youth, 59(1), 5-13. doi:10.1080/1045988X.2014.919136

Hargreaves, A. (2003). Teaching in the Knowledge Society. New York and London: Teachers College Press, Columbia University.

Havik, T., \& Westergård, E. (2020). Do teachers matter? Students' perceptions of classroom interactions and student engagement. Scandinavian Journal of Educational Research, 64(4), 488-507. doi:10.1080/00313831.2019.1577754

Hein, V., Koka, A., \& Hagger, M. S. (2015). Relationships between perceived teachers' controlling behaviour, psychological need thwarting, anger and bullying behaviour in high-school students. Journal of Adolescence, 42, 103-114. doi:10.1016/j.adolescence.2015.04.003

Hornstra, L., Mansfield, C., Van der Veen, I., Peetsma, Th., \& Volman, M. (2015). Motivational teacher strategies: the role of beliefs and contextual factors. Learning Environments Research, 18, 363-392. doi:10.1007/s10984-015-9189-y

Jang, H., Kim, E. J., \& Reeve, J. (2016). Why students become more engaged or more disengaged during the semester: A self-determination theory dual-process model. Learning and Instruction, 43, 27-38. doi:10.1016/j.learninstruc.2016.01.002 
Lam, S. F., Jimerson, S., Kikas, E., Cefai, C., Veiga, F.H., Nelson, B., Hatzichristou, C., Polychroni, F., Basnett, J., Duck, R., Farrell, P., Liu, Y., Negovan, V., Shin, H., Stanculescu, E., Wong, B. P. H., Yang, H. F., \& Zollneritsch, J. (2012). Do girls and boys perceive themselves as equally engaged in school? The results of an international study from 12 countries. Journal of School Psychology, 50, 77-94. doi:10.1016/j.jsp.2011.07.004

Lam, S. F., Jimerson, S., Shin, H., Cefai, C., Veiga, F. H., Hatzichristou, C., Polychroni, F., Kikas, E., Wong, B. P. H., Stanculescu, E., Basnett, J., Duck, R., Farrell, P., Liu, Y., Nelson, B., Yang, H. F., \& Zollneritsch, J. (2016). Cultural universality and specificity of student engagement in school: The results of an international study from 12 countries. British Journal of Educational Psychology, 86(1), 137-153. doi:10.1111/bjep.12079

Lam, S. F., Jimerson, S., Wong, B. P. H., Kikas, E., Shin, H., Veiga, F. H., Hatzichristou, C., Cefai, C., Negovan, V., Stanculescu, E., Yang, H. F., Liu, Y., Basnett, J., Duck, R., Farrell, P., Nelson, B., \& Zollneritsch, J. (2014). Understanding and measuring student engagement in school: The results of an international study from 12 countries. School Psychology, 29(2), 213-232. doi:10.1037/spq0000057

Lietaert, S., Roorda, D., Laevers, F., Verschueren, K., \& de Fraine, B. (2015). The gender gap in student engagement: The role of teachers' autonomy support, structure, and involvement. British Journal of Educational Psychology, 85, 498-518. doi:10.1111/bjep.12095

Liu, W. C., Wang, L. C. K., \& Ryan, R. M. (2016). Understanding motivation in education: Theoretical and practical considerations. In: W. C. Liu, L. C. K. Wang and R. M. Ryan (red.). Building autonomous learners: Perspectives from research and practice using selfdetermination theory (pp. 1-7). Singapore: Springer.

Niemiec, C. P., \& Ryan, R. M. (2009). Autonomy, competence, and relatedness in the classroom: Applying self-determination theory to educational practice. Theory and Research in Education, 7(2), 133-144. doi:10.1177/1477878509104318

Reeve, J. (2006). Teachers as facilitators: What autonomy-supportive teachers do and why their students benefit. The Elementary School Journal, 106(3), 225-236. doi:10.1086/501484

Reeve, J. (2009). Why teachers adopt a controlling motivating style toward students and how they can become more autonomy supportive. Educational Psychologist, 44(3), 159-175. doi:10.1080/00461520903028990

Reeve, J. (2012). A self-determination theory perspective on student engagement. In: Sandra L. Christenson, Amy L. Reschly and Cathy Wylie (eds.). Handbook of Research on Student Engagement (pp. 149-172). Boston: Springer.

Reeve, J. (2016). Autonomy-supportive teaching: What it is, how to do it. In: W. C. Liu, L. C. K. Wang and R. M. Ryan (red.). Building autonomous learners: Perspectives from research and practice using self-determination theory (pp. 129-152). Singapore: Springer. 
Reeve, J., \& Cheon, H. S. (2014). An intervention-based program of research on teachers' motivating styles. In: S. Karabenick and T. Urdan (eds.). Advances in motivation and achievement (pp. 297-343). Bingley: Emerald Group Publishing.

Reeve, J., \& Jang, H. (2006). What teachers say and do to support students' autonomy during a learning activity. Journal of Educational Psychology, 98(1), 209-218. doi:10.1037/00220663.98.1.209

Reeve, J., Bolt, E., \& Cai, Y. (1999). Autonomy-supportive teachers: How they teach and motivate students. Journal of Educational Psychology, 91(3), 537-548. doi:10.1037/00220663.91.3.537

Reeve, J., Jang, H. R., \& Jang, H. (2018). Personality-based antecedents of teachers' autonomysupportive and controlling motivating styles. Learning and Individual Differences, 62, 12-22. doi:10.1016/j.lindif.2018.01.001

Ryan, R. M., \& Deci, L. E. (2000). Self-determination theory and the facilitation of intrinsic motyvation, social development and well-being. American Psychologist, 55, 68-78. doi:10.1037/0003-066X.55.1.68

Ryan, R. M., \& Deci, L. E. (2017). Self-determination theory: An introduction and overview. In: Selfdetermination theory: Basic psychological needs in motivation, developmentm and wellness (pp. 3-29). New York: Guilford Pres.

Ryan, R. M., \& Deci, L. E. (2019). Brick by brick: The origins, development, and future of selfdetermination theory. In: A. J. Elliot (ed.). Advances in motivation science (pp. 111-156). Cambridge: Elsevier Inc.

Strati, A. D., Schmidt, J. A., \& Maier, K. S. (2017). Perceived challenge, teacher support, and teacher obstruction as predictors of student engagement. Journal of Educational Psychology, 109(1), 131-147. doi:10.1037/edu0000108

Van de Vijver, F., \& Hambleton, R. K. (1996). Translating Tests: Some Practical Guidelines. European Psychologist, 1, 89-99. doi:10.1027/1016-9040.1.2.89

West, S. G., Finch, J. F., \& Curran, P. J. (1995). Structural equation models with nonnormal variables: problems and remedies. In: R. H. Hoyle (ed.). Structural equation modeling: Concepts, issues and applications (pp. 56-75). Newbery Park, CA: Sage.

Received: 09-09-2020

Accepted: 03-12-2020 